\title{
Information Seeking Behaviour by the Research Scholars \& Faculty Members: A Survey Study of Kurukshetra University Kurukshetra in the Disciplines of Life Science
}

\author{
${ }^{1}$ Anil Kumar (Gold Medalist), ${ }^{2}$ Nasima Salmani, ${ }^{3}$ Sukhleen Baweja \\ ${ }^{I}$ (Librarian, Swift Group of Colleges, Rajpura, Patiala (Punjab), India) M.Sc Library, M Phil Library Sc. and \\ Pursuing Ph. D in K.U.K) \\ ${ }^{2}$ (Asst. Prof. Swift Institute of Mgt \& Computer Science, Rajpura, Patiala) M.A, M.Phil (English) \\ ${ }^{3}$ (Asst. Prof. Swift Institute of Mgt \& Computer Science, Rajpura, Patiala) MCA
}

\begin{abstract}
The present study has been undertaken to assess the Information Seeking Behaviour by the Research scholars \& Faculty members: A survey study of Kurukshetra University Kurukshetra in the disciplines of Life Science. A well structured questionnaire was distributed among the research-scholars and teachers of seven departments viz Botany, Bio-Chemistry, Biotechnology, Zoology, Microbiology, Home Science and Institute of Environment Studies under the Life Science in K.U.K. The responses were gathered from 121 users (50 Teachers and 71 Research Scholars).The findings of the survey reveal useful facts about the Information Seeking Behaviour by Kurukshetra University Kurukshetra. 28.92\% of the respondents were always use the information by the library daily, and same $28.92 \%$ sometimes with the requirement of information by the subject of interest. In fact $22.31 \%$ of the respondents were always uses the information weekly, $3.30 \%$ sometimes with the statement. Only $16.52 \%$ of the respondents were always uses the information twice in a week. On the basis of the findings, it was suggested that in order to improve the speed of Internet should be increased and the respondents can speedily access the information and utilize the information by the important work i.e. research work, education work, writing paper/presenting paper, administrative work, entertainment and also their download relevant materials. So provide better provision for the library should organized training programme for the information professionals so that they can know about different search interface, latest changes of the journals site and develop sophisticated searching and retrieval skills or techniques. Most of respondents were suggested that Kurukshetra University Kurukshetra should take necessary steps to utilize the library must take improve the internet, and aware the students about E-Journals \& E-resources available in INFLIBNET.
\end{abstract}

Keywords: E-Journals/Resources, Information, Information seeking behavior, Kurukshetra University Kurukshetra, Library, Life Science, use.

\section{Introduction}

The present era is an era of information \& knowledge revolution. Information is a key issue in the information age. The real challenge of this is not producing information or storing information has a crucial role in the advancement of knowledge, decision making, avoidance of duplication of efforts and technology transfer.

There is a universal assumption that man born innocent or ignorant and should actively seek knowledge. Information behavior is a broad term encompassing, the ways individuals articulate their information needs, seek, evaluate, select and use information. Information is considered as an important resource that contributes towards the development of a nation. It provides the core of the development of knowledge, the basis for innovation, the resources for informed citizenry \& as a result, becomes commodity for progress of a society. Acknowledging the significance of information in national development, (Wasserman, 1991) noted "it is not an accident that the developed nations are those in which information products \& services have been brought into being through computer intervention." Members of a society acquire the needed information from a variety of sources. However, several of these sources are expensive, complex or difficult for individuals to acquire and use. Therefore, the role of libraries becomes vital in meeting the information needs of individuals in the society. In order to accomplish this task effectively, libraries must have a thorough understanding of information needs and information seeking behavior of users.

With the progress of civilizations and the advancement of science \& technology, the compounded global store of intellectual capital has tremendously increased \& the media of communication of accumulated intellectual capital of the world has expanded. The vast and increasing mass of knowledge \& information is 
being enshrined not only in books \& serials, but also in technical \& scientific reports, patents, standards and specifications, transactions, trade circulars, reprints, off- prints, micro documents \& photocopies etc.

\section{Concept of Information}

The term 'Information' has been derived from the Latin words 'Forma' \& 'Formatio'. Both these terms convey more or less the same meaning of giving shape to something $\&$ forming a pattern. Information means the communication of knowledge about an event or given condition or the spread of knowledge derived from observation, study or instruction. There are terms such as knowledge, facts, data, news, messages etc. used as synonyms or near synonyms to information.

\section{Definitions of Information}

In information science, the concept of information is defined in many different ways. In the following is a definition that has through the cognitive approach relations with modem conception of learning. In the cognitive viewpoint of information science, Belkin (1978) "the information associated with a text is the generator's modified (by purpose, intent, knowledge of recipient's state of knowledge) conceptual, structure which underlines the surface structure (e.g. language) of that text".

Ingwersen (1995) as information being "the resulted of a transformation of the generator's cognitive structures (by intentionality, model of recipients' state of knowledge, and in the form of signs), and "on the other hand information is something - a structure- which, when perceived, may affect and transform the recipients state of knowledge".

Dervin \& Nilan (1986) "something constructed by human beings"

Turnor (1988) "Information is a key resource that can bring about change \& improvement in the society".

\section{Importance of Information}

Information is applied to various areas of human activities. These include growth of knowledge \& wisdom, decision making \& management, research \& development, manufacture \& industry, education, training $\&$ academic writing. It is information, which after tested over a long period of time by a continuous stream of minds resulting in its acceptance as truth, become wisdom, as information is a vital input in research education \& training, industry \& manufacturing.

\section{Information Need}

Information need is often understood in information science as evolving from a vague awareness of something missing and as culminating in locating information that contributes to understanding and meaning. Information need is described as an anomalous state of knowledge or a gap in individual's knowledge in sensemaking situations.

\section{Kinds of Information Needs}

The information needs of the users vary in particular cases on a particular point of time. In general there are four kinds of information needs:

* Current Information Need: in order to keep the users up to date in their respective field of development the necessity of current information is intended to make available right information in the right format of user at the earliest possible.

* Exhaustive Information Need: this necessitates when particular information user needs particular information exhaustively. Detailed information on a particular field helps the users to draw suitable conclusion in a particular area of activity.

* Everyday Information Need: Day to day activities vary from person to person. Different users need different kind of information at different points of time. There are some users who need information on a particular activity every day.

* Catching up Information Need: precise information is the characteristics of this kind of need of the users. The information should be as simple and to point as possible, so that the users can easily catch it.

\section{Information Seeking}

Wiberley (1989) defines 'Information seeking' as "Information seeking is a basic activity indulged in by all people \& manifested through a particular behavior”.

\section{Information Behavior}

Information behavior is the totality of human behavior in relation to sources \& channels of information including both active \& passive information seeking \& information use. Thus it includes face to face 
communication with others as well as passive reception of information as in for example watching T.V advertisements without any intention to act on the information given. Information behavior can be defined by the general model of information behaviour developed by Wilson 1997. According to Wilson, a general model of information behaviour needs to include at least the following three elements:

* An information need and its drivers, i.e., the factors that give rise to an individual's perception of need;

* The factors that affect the individual's response to the perception of need;

* The processes or actions involved in that response."

Taylor (1991) defines information behavior as the product of certain elements of the information use environment. The elements are:

* The assumptions formally learned or not, made by a defined set of people concerning the nature of their work.

* The kinds and structure of the problems deemed important and typical by this set of people.

* The constraints and opportunities of typical environments within which any group or subgroup of this set of people operates and works.

* The conscious, and perhaps unconscious, assumptions made as to what constitutes a solution, or better said, a resolution of problems, and what makes information useful and valuable in their contexts.

\section{Information Seeking Behavior}

Information seeking behavior is a broad term encompassing the ways individuals articulate their information needs, seek, evaluate, select and use information. Thus information seeking behavior is the purposive seeking for information as a consequence of a need to satisfy some goal. It may be through published or unpublished documents, communicating with colleagues.

Kriekelas (1983) "As any activity of an individual that is undertaken to identify and perceives that the current state of possessed knowledge is less than that needed to deal with some issue".

\section{Information Seeking Models}

The influence of technology on Information Seeking is also providing a new set of alternative models that more accurately describe the Information Seeking process as a dynamic activity. Models of Information seeking attempts to describe the process a user follow to satisfy an information need. It is important to examine information seeking models as what students actually do when searching for information may be very different from what librarians think the students do.

\section{Wilson's And Krieklas' Model Of Information Seeking}

This model illustrates the relationship between the concepts of user, need, uses and user behaviour. The model suggests that the user perceives a need in the context of the user's environment. That is, in a given environment or event (e. g. University course) the user will perceive an information need. The perceived need will lead the user to search for information, making demands upon a variety of information sources. These information sources include information systems (university libraries and public libraries); human resources (experts, professors, colleagues); and other resources (personal library, media).

Information seeking may lead to either a success or a failure. If successful, information is located which will be used. This may result in the satisfaction or non-satisfaction of the original perceived need. Satisfaction occurs when the located information has been analyzed and satisfies the original need. With nonsatisfaction, the information seeking process may be repeated until satisfaction occurs. A failure to find information may result in the process of information seeking being continued. The information seeking process ends when the perceived need has been satisfied. 


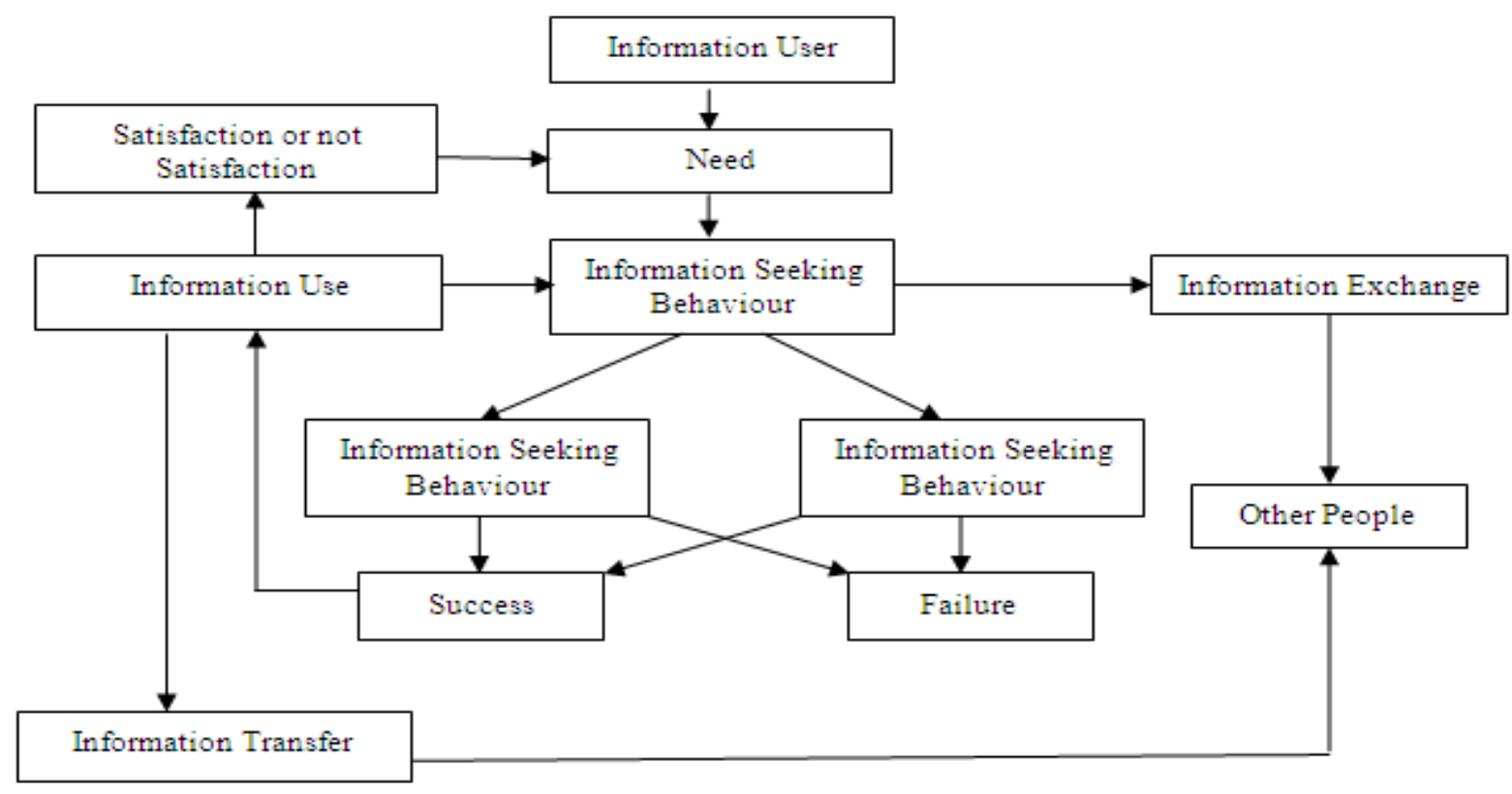

Figure 1. Wilson's \& Krieklas Model of Information Behavior (June 1999)

\section{Belkin's Information Seeking Process Model}

Belkin provides another view of the Information Seeking process, described as Information Seeking Strategies (ISS). The set of task are:

* Browsing - scanning or searching a resource

* Learning - expanding knowledge of the goal, problem, system or available resource through selection

- Recognition - identifying relevant items (via system or cognitive association)

* Meta information - interacting with the items that map the boundaries of the task.

This model is not linear or like a typical waterfall flow of process. Belkin stress this non-linearity in that he suggests that model should support "graceful movement" among the tasks.

\section{Eisenberg And Berkowitz's Big Six Skills Model}

Eisenberg and Berkowitz proposed the Big Six Skills that represents a general approach to information problem solving, consisting of six logical steps or stages. The order of the stages changes with each search venture, but each stage is necessary in order to achieve a successful resolution of an information problem. The big six skills involve:

* Task Definition: The student needs to define the problem from an information point of view.

* Information Seeking Strategies: Once the student has clearly defined the information problem, then he must decide which and what information sources are the most appropriate to solve the task.

* Locating and access: Locating and access is the implementation of the information seeking strategy.

* Use of information: Once student have found the needed information, they can employ skills to use the information.

* Synthesis: Is the application of all information to the defined task. It involves restructuring and repackaging the information into a new different form.

* Evaluation: Evaluation is the examination and assessment of the information problem solving process. It determines whether the information found met the defined task.

\section{Ellis Model Of Information Seeking}

Ellis (1998) propose and elaborate a general model of information seeking behaviours based on studies of the information seeking patterns of social scientist, research physicists and chemists, and engineers and research scientist in an industrial firm. One version of the model describes six categories of information seeking activities as generic: starting, chaining, browsing, differentiating, monitoring, and extracting.

* Starting comprises those activities that form the initial search for information identifying sources of interest that could serve as starting points of the search. Following up on these new leads from an initial source is the activity of Chaining. 
* Chaining can be backward or forward. Backward chaining takes place when pointers or references from an initial source are followed, and is well established routine of information seeking among scientists and researchers. In the reverse direction, forward chaining identifies and follows up on other sources that refer to an initial source or document.

* Browsing is the activity of semi directed search in areas of potential search. The individual often simplifies browsing by looking through tables of contents, list of titles, subject headings, names of organizations or persons abstracts and summaries, and so on.

* Differentiating, the individual filters and selects from among the sources scanned by noticing differences between the nature and quality of the information offered. The differentiation process is likely to depend on the individual's prior or initial experience with the sources, word-of-mouth recommendations from personal contacts, or reviews in published sources.

* Monitoring is the activity of keeping abreast of developments in an area by regularly following particular sources. The individual monitors by concentrating on a small number of what are perceived to be core sources.

* Extracting is the activity of systematically working through a particular source or sources in order to identify material of interest. As a form of retrospective searching, extracting may be achieved by directly consulting the source, or by indirectly looking through bibliographies, indexes, or online databases.

In follow-up studies, Ellis adds two more features to his model: verifying, where the accuracy of the information is checked and ending, which typifies the conclusion of the information seeking process such as building final summaries and organizing notes.

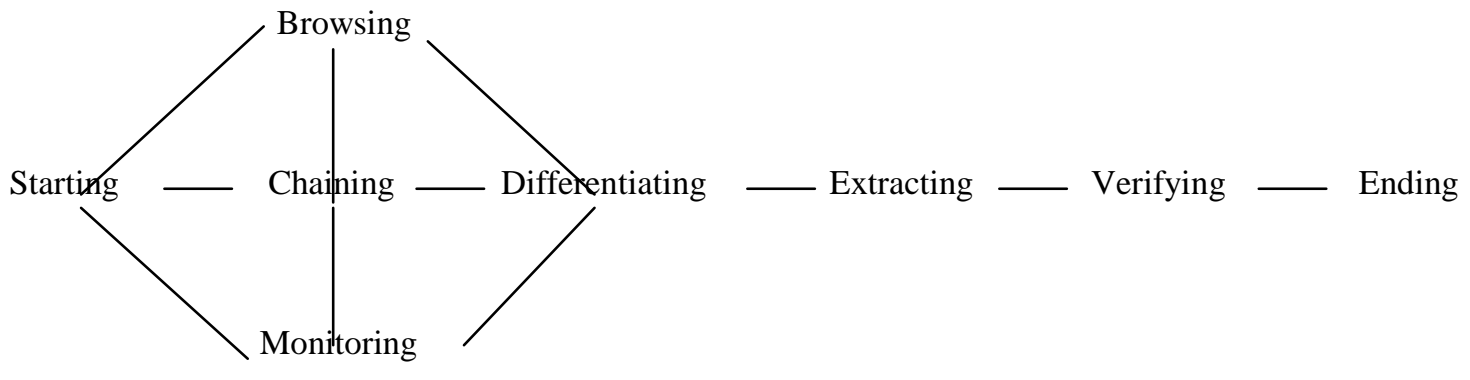

\section{A stage process version of Ellis's behavioural framework}

Currently, Ellis has modified his model's features somewhat, improving starting to surveying. Surveying further stresses the activity of obtaining an overview of the research terrain or locating key people operating in the field. Differentiating has been refined to distinguishing, where information sources are ranked. Another new feature of the model has also been added - filtering, which capitalizes on personal criteria or mechanism to increase information precision and relevancy.

\section{v. Spink Model Of Information Seeking}

Spink proposes a model of the search process, derived from empirical research, which identifies user judgements, search tactics or moves, interactive feedback loops, and cycles as constituting the search process of a person in interaction with an IR system. 
Spink describes the model as follows:

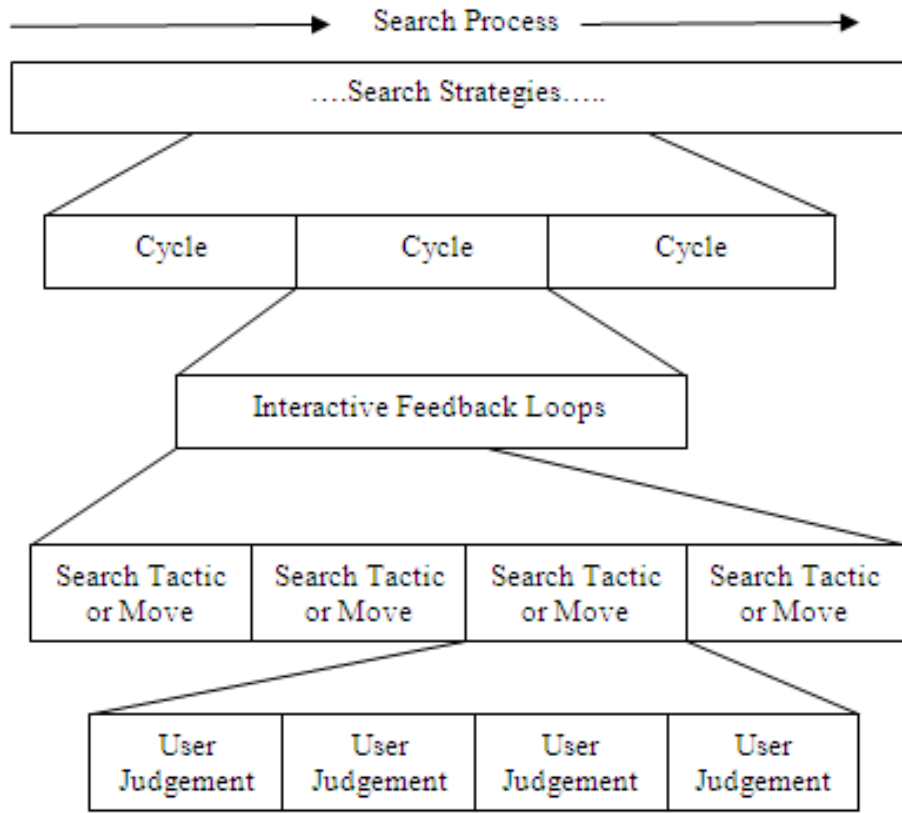

Spink's Modal of the IR interaction process

Each search strategy may consist of one or more cycles (one or more search commands ending in the display of retrieved items). Each cycle may consist of one or more interactive feedback occurrences (user input, system output, user interpretation and judgement, user input). An input may also represent a move within the search strategy and may be regarded as a search tactic to further the search. Each move consists of a user input or query requesting a system's output'

\section{Review of Related Literature}

The review of the literature is an important part of scientific approach and is carried out in all the areas of research.

Kim and Chi (2014) stressed over the swift development of this technical era in which information and communication technologies spread all over the world rapidly but it created a generation gap as the most effective exclusion of elderly. The authors found that conducted the study in korea's metropolitan areas to emphasize the different ways of information seeking behavior as well as the factors that affected the attitudes of elderly people. The major findings of this field study revealed that the elderly people gave accent to interpersonal relationships while they sought information. It also reflected that they sought information. It also reflected that they actively seek information from human information sources, which in turn triggers further information seeking. No doubt seniors use a number of digital devices but they faced hurdles which prevented them to search information of their interest by using these digital devices. Hence the present study focused on meaningful insight which became a helping hand to investigate 'new seniors' who parted the generation gap by possessing/imbibing the digital literacy in future.

Parveen Kumar (2013) reviewed studies has been undertaken to identify the Information Seeking Behaviour by the faculty members of the BPS Women University in Khanpur. The study was based on questionnaire method. The major finding of the survey reveal useful facts about the study was faculty member uses Google for searching information. The majority of faculty says unavailability of information on the internet. His study reveals that the majority of faculty members sought information for preparing lectures, keeping knowledge up to date and research work. Faculty members used several methods to seek information, but they prefer to consult a knowledgeable person in the field.

Rupp-Serrano and Robbins (2013) reviewed studies has been undertaken to explore the Information Seeking Behaviour were used by academic educational faculty members of twenty large public research Universities. They reflected with an observation how frequently educational faculty accessed information \& also examined how they prepared themselves up-to-date on current developments in the field. The present study also highlighted about electronic sources used by information seekers. Simultaneously the faculty emphasized the importance of electronic access to scholarly journals, library databases and value of books whether print or electronic for fulfilling the information and research needs. 
Shakeel Ahmed and Venayagamoorthy (2013) presented a special study regarding information seeking behavior of business school students in Dubai. The main feature of this research was to evaluate the information seeking behavior with great effort to determine the sources consulted \& the general pattern of information gathering system by the students of business school. A well constructed survey prepared \& data were collected 2003 students from eighteen Universities \& colleges located in Academic city Dubai with the help of questionnaire. So the present study discovered the finding of academic related information was the prime reason for need of information, internet \& electronic resources are the most vital source of information. It was a typical representation of the population of the business school students.

Ramesh (2012) attempted a study to analyze the information needs and seeking behavior of information resources of the library by the faculty members of the ICFAI Business School, Hyderabad. For this evaluation a well structured questionnaire was constructed data of Seventy Faculty Members were collected \& analysis. The major findings of the survey revealed useful facts about indicated that the library professionals were required to help them for maximum utilization of library resources and made the faculty members aware to access the library resources available to them.

Natarajan (2012) surveyed a description about electronic resources (e-resources) and their different types. With the help of study undertake the Information seeking behavior of students, researchers and faculty in this electronic environment was discussed. The role of library professionals in making the e-resources available to different types of user community was elaborated. Hence it had been concluded that the availability of eresources \& easy to access helps the students and researchers to avail their benefit in research.

Khan and Shafique (2011) studied the Information seeking behavior of faculty members of government colleges of Bhawalpur \& found that respondents were mostly seeked information for lecturer preparation, personal competency improvement and current awareness. Books and monographs, face to face discuss with colleagues and friends were the most used formal \& informal sources of information. Institutional library \& personal collection were heavily used to acquire information. All the respondents faced problem due to lack of computers. They preferred English language for reading material and preferred print format. Google was mostly used search engine most respondents had not received and formal training or orientation for using online information resources. The study suggested that college libraries should be equipped with computers, CDs, Internet \& latest research journals and workshops \& seminars should be arranged.

Bhatia and Rao (2011) studied the information seeking behavior of students at Dev Samaj College, Chandigarh and found that although students used internet but less than fifty percent of the respondents were not aware about e-resources. Students used search engines as a major source to access e-resources for their information needs \& for the purpose of updating knowledge on their subjects of interest. Limited resources \& services available in the college library affected students information seeking \& gathering activities. In order to overcome the hindrances in accessing the e-resources, the study recommended to organize awareness programmes on use of e-resources and to provide training on web searching to the students.

Raja (2010) in his study on information seeking behavior of researches of central drug research institute (CDRI), Lucknow found that most researchers visited the library weekly to collect reading material. The OPAC \& photocopying were the most used services for searching \& most researchers preferred to search by subject literature searches was performed using the library's international network. Most users used the internet services for e-mail \& faced the problem of slow downloading. Newspapers \& bibliography services were most used research services. Most researches used the library/s e-journals and attended conferences, seminars \& workshops frequently. The CDRI library had provided effective services to researchers. Most users were satisfied with the services provided by the library \& there was a good application of information communication Technology in the library. Information seeking behavior differed from one discipline to another $\&$ from one institution or library to another. A sizable number of users were not satisfied with library opening hours. The study suggested that library information system must be capable of handling the complex information need \& demands of researchers.

Tenopir et al. (2009) studied the reading patterns of science, social science, technology, and medical university faculty members. The study was restricted to university science faculty members and their response was compared over time. Data for the study were collected periodically from 1977 to present through questionnaire. Study showed that the information seeking and reading patterns of science faculty changed with the growth of electronic journals. Study also found that the average number of readings per year per science faculty member continues to increase, while the average time spent per reading decreases.

Qureshi et al. (2008) examined the information needs and information-seeking behavior of students of nine universities in Pakistan. The study was carried out with the objective to examine the behaviour of students towards the information, to identify the main sources of information, to determine level of awareness regarding the sources and to establish whether students have had any instruction on use of resources or not. Questionnaire method was the chief instrument for collecting data, and one thousand students responded to the study. Statistical tools like correlation and regression were used to analyze data. Study found that educational and 
cultural background. Surrounding Environment and student participation have a positive impact on the information-seeking behavior of students. Study also revealed that modem digital libraries, interfaces and web database sources etc also have an influence on students "information behavior.

Liao et al. (2007) compared the information needs and Information-Seeking Behavior of international graduate students and American graduate students at Virginia Tech. The objective of this comparative study was to identify how graduate students having different characteristics use various information sources and also to obtain insights into international graduate student's information-seeking behavior. Web based questionnaire method was adopted for collecting data. Three hundred and sixty two graduate students $(6.3 \%)$ responded to the study. Various statistical techniques namely Chi-square, ANOVA, F-test were employed for the analysis of data. Study revealed that international students use libraries more actively and often than American students. Study also showed some distinctive characteristics of the style of study of international graduate students, and also demonstrated that the impact of language or cultural communication barriers and technology barriers affects the international student's information access.

George et al. (2006) studied the information seeking behavior of Graduate students of all disciplines \& departments at Carnegie Mellon University \& found that graduate students often began with a meeting with professors who provide direction, recommend and provide resources. Other students helped to shape graduate students research activities \& university library personnel provided guidance in finding resources. The internet played a major role, although students continued to use print resources. Convenience, lack of sophistication in finding and using resources \& course requirements affected their information behavior.

Wang (2006) studied the academic researchers' use of internet information and communication technologies (IICT) to support information seeking activities. The goal of the study was to gain insight into disciplinary and cultural difference of information seeking in the internet era. In depth face-to-face interview method was used to collect data. Fifty five researchers from United States and ten from China were interviewed for the study. Quantitative data were coded and analyzed using SPSS and quantitative data using QSR N6. To compare disciplinary differences, only faculty participants were included from the selected disciplines and countries. The preliminary results of the study showed differences in perception of importance of (IICT's) to research. The project was continuing to include more participants from different cultures.

Asemi (2005) carried out a study to understand the information searching habits of internet users at the Medical University of Isfahan. The aim of the study was to investigate the status of information searching nature of the users on internet. Data was collected using a questionnaire followed by interview with users from five faculties. One hundred and eighty eight persons responded to the study. Study revealed that students use internet significantly \& it occupies an important place among various sources. Study also observed that electronic media has not replaced print media.

Heinstrom (2005) investigated the information behaviour from a physiological perspective by relating information seeking to personality traits and study approaches. Author studied ISB in relation to the five factor personality theory. The study was based on three hundred and five university students who were in the process writing their master's thesis. Research design was quantitative and consisted of three questionnaires. Statistical tools used for analysis include factor, correlation and regression analysis. The main finding of study was that students information behaviour could be grouped into three patters- fast surfing, broad scanning and deep diving, which were linked to personality traits and study approaches.

Purnima and Vikas (2005) have made a study on information needs of the college faculties of higher education in Manipur. The study reveals that except for few colleges/universities, most of the faculties were not aware of the IT, due to lack of infrastructure in their libraries. They have studied about information needs of the faculties of colleges and universities. They studied on the use of computers, internet, e-journals, and digital resources.

Roberts (2004) compared the information seeking skills of senior student nurses of three preregistration nurse education programme. The study was carried out to explore the senior students' information seeking skills and to investigate whether students from different programmes utilized different seeking strategies. Purposive sampling strategy was employed for data collection and data analysis was carried out in two phases. Two hundred and fifty three nurse students participated in the survey. Study revealed both similarities and differences between the groups. The integrated degree programme participants displayed more systematic approach to information acquisition, while registered general nurse programme participants preferred the use of a model.

Hillet (2002) carried out a study to measure the contentment of faculty and students with library services at the University of Washington. The study investigated the importance of resources, the reasons for the use or non use of libraries, information resources and their priorities for library services and resources. The study focused on the difference and also similarities between scientists/engineers and other academic areas in their library use and information needs at Washington University. The survey population included all faculties and random samples of graduate students were taken. Questionnaire method was used for the study. Survey 
Information Seeking Behaviour by the Research Scholars \& Faculty Members: A Survey Study .....

results showed high satisfaction levels and a shift towards remote use and increased importance of electronic resources. Survey results also documented significant variations between groups and academic areas. The differences in academic areas are most pronounced in priorities, use patterns, importance of information resource formats and the impact of new technology on library use.

Prekop (2002) carried out a qualitative study of a complex collaborative information seeking activity drawn from military domain. Most of the information seeking studies focused on the ISB of individuals rather than a collaborative information seeking. This study investigates the collaborative ISB performed by a working group of command and control support study. Structured interviews were used for eliciting data and were supported by minutes of the working groups meetings. A total of twenty eight participants were involved in the study. The study identified the contexts, roles and patterns of interaction that emerged from the collaborative information seeking activities undertaken by the study.

Nicholas et al. (2001) explored the relationship between the expressed health information needs and what health information seekers actually found. Data was collected from three sources namely; questionnaire hosted on website, a touch-screen health information kiosk and Kiosk transaction logs. Results of the study showed that reasons for visit to the system has an impact on the type of information viewed and identified four types of internet users. The study examined the information behaviour of health information users also.

Majeed et al. (2000) in their study explored the information needs and ISB of Malaysian Agricultural scientists. Study was carried out in five major Malaysian Agricultural institutions. Questionnaire method was used for data collection and data was collected from two hundred and thirty six respondents followed by interviews with some respondents. Study showed that majority of the scientists' preferred primary sources of information. Study also revealed that research scientists spend $16 \%$ of their office time on literature search and reading. Another important observation of the study was that $43 \%$ of the respondents were unable to keep in touch with the latest scientific literature due to deficient library collection and facilities.

\section{Research Methodology}

For the purpose of the study, a questionnaire was designed (Appendix-1). The questionnaire was pretested before using it with the survey population. All the respondents were given the same questionnaire irrespective of their status. The questionnaire was distributed to any those respondents who willingly agreed to participate in the study. The respondents were interviewed also to fill in the gaps, if any.

\section{Objectives of the Study}

The present study intends to investigate the following objectives:

* To identify the Purpose/information needs by the teachers and research Scholars.

* To study their information gathering activities.

* To find the internet based information resources, services \& with prefer to read Information.

* To find out the preferred place for information usage and time spent per week by the Teachers and Research Scholars.

* To find out the Information sources that you are need.

* To examine \& understand the common problem faced by the users to access the information resources.

\section{Scope of the Study}

The study is being undertaken in order to identify the Information seeking behavior by the Research Scholars \& Faculty members: A survey study of Kurukshetra University Kurkshetra in the disciplines of Life Science. The study will include research scholars \& faculty members of all the seven departments viz Botany, Bio-Chemistry, Biotechnology, Zoology, Microbiology, Home Science and Institute of Environment Studies following under the disciplines of Life Science.

\section{Statement of the Problems}

Today information technology has developed rapidly \& has a huge impact on access to information. These days all the researcher's weather research scholars \& faculty member mostly depend on the internet for information gathering for their research, entertainment, writing paper /presentation and up to date information. As thousands of periodicals, CD's, research papers, e-thesis, e-journals, \& resources are available on internet either free or on payment and thus literature collection has become quite easy keeping in view these facts the present study is taken up "Information Seeking Behaviour by the Research Scholars \& Faculty members: A survey study of Kurukshetra University Kurukshetra in the disciplines of Life Science". 
IV. Analysis \& Interpretation:

Table 1. Gender wise Access the Information

\begin{tabular}{|c|l|c|}
\hline Sr. No & Gender wise & Response No \% \\
\hline 01 & Male & $57(47.10 \%)$ \\
\hline 02 & Female & $64(52.89 \%)$ \\
\hline Cumulative Total & $\mathbf{1 2 1}(\mathbf{1 0 0 \% )}$ \\
\hline
\end{tabular}

Table 1. shows that access of Information by the Research scholars \& faculty members in Kurukshetra University Kurukshetra in the disciplines of Life Science among male and female. Male respondents are 47.10\% than female users which are $52.89 \%$.

Table 2. Status wise Access the Information

\begin{tabular}{|c|l|c|}
\hline Sr. No & Status wise & Response No \% \\
\hline 01 & Professor & $10(8.26 \%)$ \\
\hline 02 & Associates Professor & $08(6.61 \%)$ \\
\hline 03 & Asst. Professor & $32(26.44)$ \\
\hline 04 & Research Scholars & $71(58.67)$ \\
\hline
\end{tabular}

Results in Table 2. Show that use/access of information by Kurukshetra University Kurukshetra in the disciplines of Life Science is more popular among research scholars and junior faculty members. Out of total respondents 58.67\% research scholars, 26.44\% Asst. Professor and than 8.26\% Professor, also 6.61\% Associates Professor are using/accessing the Information.

Table 3: frequency of Visit the Library

\begin{tabular}{|c|l|c|c|c|c|c|c|}
\hline Sr. No & \multicolumn{2}{|c|}{ Visit the library } & Always & Often & Usually & Sometimes & Never \\
\hline \multirow{2}{*}{01} & \multirow{2}{*}{ Daily } & T & - & - & - & $25(20.66)$ & - \\
\cline { 3 - 9 } & & R.S & $18(14.87)$ & $12(9.91)$ & $5(4.13)$ & $10(8.26)$ & - \\
\hline 02 & \multirow{2}{*}{ Weekly } & T & $5(4.13)$ & $3(2.47)$ & $4(3.30)$ & $1(0.82)$ & - \\
\cline { 3 - 9 } & & R.S & $5(4.13)$ & $6(4.85)$ & $4(3.30)$ & $3(2.47)$ & - \\
\hline \multirow{2}{*}{03} & \multirow{2}{*}{ Twice in a week } & T & $2(1.65)$ & $2(1.65)$ & $8(6.61)$ & - & - \\
\cline { 3 - 9 } & & R.S & $2(1.65)$ & $3(2.47)$ & $3(2.47)$ & - & - \\
\hline 04 & \multirow{2}{*}{ Occasionally } & T & - & - & - & - & - \\
\cline { 3 - 9 } & & R.S & - & - & - & - & - \\
\hline
\end{tabular}

\section{T= Teacher; R.S= Research Scholars}

Table 3. shows the respondents that various availability available use the Information by the library. $28.92 \%$ respondents are always using the Information need to access by the library daily and same $28.92 \%$ sometimes. K.U.K in the disciplines of Life Science $22.31 \%$ users are always uses the information by weekly, $3.30 \%$ sometimes and also only $16.52 \%$ twice in a week.

Table 4: Purpose/Information Need to Users

\begin{tabular}{|c|c|c|c|c|c|c|c|}
\hline Sr. No & \multicolumn{2}{|c|}{ Purpose/Information need to Users } & Always & Often & Usually & Sometimes & Never \\
\hline \multirow[t]{2}{*}{01} & \multirow[t]{2}{*}{ Teaching } & $\mathbf{T}$ & $25(20.66)$ & $10(8.26)$ & $15(12.39)$ & - & - \\
\hline & & R.S & - & - & - & $15(12.39)$ & - \\
\hline \multirow[t]{2}{*}{02} & \multirow{2}{*}{ Research Work } & $\mathbf{T}$ & $10(8.26)$ & $15(12.39)$ & $20(16.52)$ & $5(4.13)$ & - \\
\hline & & R.S & $40(33.05)$ & $10(8.26)$ & $20(16.52)$ & - & - \\
\hline \multirow[t]{2}{*}{03} & \multirow[t]{2}{*}{ Education } & $\mathbf{T}$ & $10(8.26)$ & $10(8.26)$ & $20(16.52)$ & $11(9.09)$ & - \\
\hline & & R.S & $35(28.92)$ & $15(12.39)$ & $20(16.52)$ & - & - \\
\hline \multirow[t]{2}{*}{04} & \multirow[t]{2}{*}{ Writing paper \& presenting paper } & $\mathbf{T}$ & $14(11.57)$ & $5(4.13)$ & $6(4.85)$ & $10(8.26)$ & $10(8.26)$ \\
\hline & & R.S & $8(6.61)$ & $10(8.26)$ & $10(8.26)$ & $32(26.44)$ & $10(8.26)$ \\
\hline \multirow{2}{*}{05} & \multirow[t]{2}{*}{ Updating knowledge } & $\mathbf{T}$ & $13((10.74)$ & $12(9.91)$ & $5(4.13)$ & $10(8.26)$ & $10(8.26)$ \\
\hline & & R.S & $10(8.26)$ & $10(8.26)$ & $10(8.26)$ & $30(16.52)$ & $10(8.26)$ \\
\hline \multirow{2}{*}{06} & \multirow[t]{2}{*}{ Entertainment } & $\mathbf{T}$ & $5(4.13)$ & $5(4.13)$ & $5(4.13)$ & $35(28.92)$ & - \\
\hline & & R.S & $40(33.05)$ & $5(4.13)$ & $5(4.13)$ & $20(16.52)$ & - \\
\hline \multirow{2}{*}{07} & \multirow[t]{2}{*}{ Carry out administrative work } & $\mathbf{T}$ & $2(1.65)$ & $3(2.47)$ & $5(4.13)$ & $30(24.79)$ & $10(8.26)$ \\
\hline & & R.S & $5(4.13)$ & $2(1.65)$ & $3(2.47)$ & $10(8.26)$ & - \\
\hline
\end{tabular}


Information Seeking Behaviour by the Research Scholars \& Faculty Members: A Survey Study .....

Most of the respondents use the library for more than one purpose. The analysis shows that among purposes the main purpose of users to use the Information for research work. In Life Science $95.04 \%$ users are always accesses the Information for research works, $4.13 \%$ sometimes with the statement and education purpose are the second purpose for which users always access the Information i.e. $90.90 \%$ and $9.09 \%$ sometimes. Entertainment are the third purpose for using the library i.e. $53.71 \%$ users always \& $45.45 \%$ sometimes. Update knowledge are the forth purpose for which users always access the information i.e. $49.58 \%$, in fact $33.05 \%$ sometimes and $16.52 \%$ never. Only $43.80 \%$ respondents are always access the information by the writing \& presenting paper, $34.71 \%$ sometimes \& $16.52 \%$ never. In Life Science disciplines of $41.32 \%$ users are access and utilize the information by teaching purpose for K.U.K \& $12.39 \%$ sometimes. Less than $16.52 \%$ users are always carrying out the administrative work of K.U.K, $33.05 \%$ sometimes and $8.26 \%$ never.

Table 5: Prefer to Use the Information Seeking Activities

\begin{tabular}{|c|c|c|c|c|c|c|c|}
\hline Sr. No & \multicolumn{2}{|c|}{$\begin{array}{c}\text { Prefer to Use Information } \\
\text { Seeking activities }\end{array}$} & Always & Often & Usually & Sometimes & Never \\
\hline \multirow[t]{2}{*}{01} & \multirow[t]{2}{*}{ Home } & $\mathbf{T}$ & $10(8.26)$ & $5(4.13)$ & - & $5(4.13)$ & - \\
\hline & & R.S & $5(4.13)$ & $10(8.26)$ & $5(4.13)$ & $2(1.65)$ & - \\
\hline \multirow[t]{2}{*}{02} & \multirow{2}{*}{ Departmental Library } & $\mathbf{T}$ & $10(8.26)$ & $1(0.82)$ & $5(4.13)$ & $2(1.65)$ & - \\
\hline & & R.S & $10(8.26)$ & $8(6.61)$ & $5(4.13)$ & $5(4.13)$ & - \\
\hline \multirow[t]{2}{*}{03} & \multirow[t]{2}{*}{ Office } & $\mathbf{T}$ & $6(4.95)$ & $4(3.30)$ & $2(1.65)$ & - & - \\
\hline & & R.S & - & - & - & - & - \\
\hline \multirow[t]{2}{*}{04} & \multirow[t]{2}{*}{ Central Library of the University } & $\mathbf{T}$ & - & - & - & - & - \\
\hline & & R.S & $6(4.95)$ & $3(2.47)$ & $2(1.65)$ & & - \\
\hline
\end{tabular}

Table 5. shows that $32.23 \%$ respondents are always using the Information by departmental library and $5.78 \%$ sometimes. In fact Kurukshetra University Kurukshetra in the disciplines of Life Science i.e. 20.66\% users are always uses the information by home and $5.78 \%$ sometimes with the requirement of information needs. Only $9.91 \%$ teachers and research scholars are use the information by office and $9.09 \%$ central library of Kurukshetra.

Table 6: Average Time Spent on Library with Users Information Need

\begin{tabular}{|c|c|c|c|c|c|c|c|}
\hline Sr. No & \multicolumn{2}{|c|}{$\begin{array}{l}\text { Average time spent on Library with } \\
\text { Users Information Need }\end{array}$} & Always & Often & Usually & Sometimes & Never \\
\hline \multirow[t]{2}{*}{01} & \multirow{2}{*}{ Less than 30 Minutes to 1 Hour } & $\mathbf{T}$ & $10(8.26)$ & $2(1.65)$ & 15 (12.39) & $10(8.26)$ & - \\
\hline & & R.S & $10(8.26)$ & $5(4.13)$ & $10(8.26)$ & $10(8.26)$ & - \\
\hline \multirow[t]{2}{*}{02} & \multirow[t]{2}{*}{1 To 2 hours } & $\mathbf{T}$ & $2(1.65)$ & $3(2.47)$ & $4(3.30)$ & - & - \\
\hline & & R.S & $15(12.39)$ & $11(9.09)$ & $4(3.30)$ & - & - \\
\hline \multirow[t]{2}{*}{03} & \multirow[t]{2}{*}{2 to 3 Hours } & $\mathbf{T}$ & $1(0.82)$ & - & $3(2.47)$ & - & - \\
\hline & & R.S & $2(1.65)$ & $1(0.82)$ & $2(1.65)$ & - & - \\
\hline \multirow[t]{2}{*}{04} & \multirow[t]{2}{*}{3 To 4 Hours } & $\mathbf{T}$ & - & - & - & - & - \\
\hline & & R.S & - & $1(0.82)$ & - & - & - \\
\hline \multirow[t]{2}{*}{05} & \multirow[t]{2}{*}{ More than 4 hours } & $\mathbf{T}$ & - & - & - & - & - \\
\hline & & R.S & & & & & - \\
\hline
\end{tabular}

Table 6. shows that Life Science teachers and research scholars are spend more times in the departmental library. $32.23 \%$ respondents are 1 to 2 hours always time spending on library by the requirement of information needs. In fact $42.97 \%$ of the users spend less than 30 Minutes to 1 hour and $16.52 \%$ sometimes. Only $7.43 \%$ Teachers \& Research scholars are spent their 2 to 3 hours and very less than $0.82 \%$ users are always access the information on library by 3 to 4 hours in the discipline of life Science from K.U.K.

Table 7: Do you use the Internet Services

\begin{tabular}{|c|l|c|c|c|c|c|c|}
\hline Sr. No & \multicolumn{2}{|c|}{$\begin{array}{c}\text { Do you Use the Internet } \\
\text { Services }\end{array}$} & Always & Often & Usually & Sometimes & Never \\
\hline \multirow{2}{*}{01} & Daily & T & $5(4.13)$ & $4(3.30)$ & $2(1.65)$ & $9(7.43)$ & - \\
\cline { 3 - 8 } & & R.S & $10(8.26)$ & $5(4.13)$ & $2(1.65)$ & $14(11.5)$ & \\
\hline 02 & \multirow{2}{*}{2 to 3 times in a week } & T & $10(8.26)$ & $5(4.13)$ & $10(8.26)$ & - & - \\
\cline { 3 - 8 } & & R.S & $25(20.6)$ & $15(12.3)$ & - & - & - \\
\hline \multirow{2}{*}{33} & T to 5 time in a Month & $1(0.82)$ & $3(2.47)$ & $1(0.82)$ & - & - \\
\cline { 3 - 8 } & & R.S & - & - & - & - & - \\
\hline 04 & \multirow{2}{*}{ Once in a month } & T & - & - & - & - & - \\
\cline { 3 - 8 } & & R.S & - & - & - & - & - \\
\hline
\end{tabular}

In Life Science disciplines of $53.71 \%$ of the respondents always use the Internet services of 2 to 3 times in a week from K.U.K. In fact only $23.14 \%$ of the users are daily use the Internet services, and $19 \%$ sometimes with 
Information Seeking Behaviour by the Research Scholars \& Faculty Members: A Survey Study .....

the statement. In Life Science disciplines of $4.13 \%$ respondents are always using the Internet services of 3 to 5 time in a month from K.U.K.

Table 8: Do you Use Internet resources

\begin{tabular}{|c|c|c|c|c|c|c|c|}
\hline Sr. No & \multicolumn{2}{|c|}{ Use of Internet Resources } & Always & Often & Usually & Sometimes & Never \\
\hline \multirow[t]{2}{*}{01} & \multirow[t]{2}{*}{ E-Books } & $\mathbf{T}$ & $15(12.3)$ & $5(4.13)$ & $10(8.26)$ & $20(16.5)$ & - \\
\hline & & R.S & $30(24.7)$ & $10(8.26)$ & $5(4.13)$ & $10(8.26)$ & $16(13.2)$ \\
\hline \multirow[t]{2}{*}{02} & \multirow[t]{2}{*}{ E-Journals } & $\mathbf{T}$ & $25(20.6)$ & $10(8.26)$ & $5(4.13)$ & $10(8.26)$ & - \\
\hline & & R.S & $40(33.0)$ & $2(1.65)$ & $18(14.8)$ & $10(8.26)$ & - \\
\hline \multirow[t]{2}{*}{03} & \multirow[t]{2}{*}{ E-database } & $\mathbf{T}$ & $10(8.26)$ & $2(1.65)$ & $15(12.3)$ & $15(12.3)$ & $8(6.61)$ \\
\hline & & R.S & $5(4.13)$ & $12(9.91)$ & $13(10.7)$ & $25(20.6)$ & $16(13.2)$ \\
\hline \multirow[t]{2}{*}{04} & \multirow[t]{2}{*}{ E-Thesis/Dissertation } & $\mathbf{T}$ & $5(4.13)$ & $7(5.78)$ & $10(8.26)$ & $10(8.26)$ & - \\
\hline & & R.S & $15(12.3)$ & $10(8.26)$ & $10(8.26)$ & $25(20.6)$ & - \\
\hline
\end{tabular}

Table 8. shows the respondents that various availability available use the Internet resources. E-Journals \& E-Books both are the top priority of the respondents in Kurukshetra University Kurukshetra in the disciplines of Life Science. More than $61.98 \%$ respondents are always using the E-books under the Internet resources, $24.79 \%$ sometimes and $13.22 \%$ never use it. In Life Science disciplines of $82.64 \%$ users are always using the E-Journals from K.U.K, $16.52 \%$ sometimes. Only $47.10 \%$ respondents are always using the E-database, $28.92 \%$ sometimes and $13.22 \%$ never use it with the requirement of Information need. In fact $47.10 \%$ teachers \& research scholars are always using the E-thesis/Dissertation and $28.92 \%$ sometimes.

Table 9: Internet Services based on Communication Channels used for Information-seeking

\begin{tabular}{|c|c|c|c|c|c|c|c|}
\hline Sr. No & \multicolumn{2}{|c|}{$\begin{array}{l}\text { Internet services based on Communication } \\
\text { channels used for Information seeking }\end{array}$} & Always & Often & Usually & Sometimes & Never \\
\hline \multirow[t]{2}{*}{01} & \multirow[t]{2}{*}{ E-mail } & $\mathbf{T}$ & $20(16.5)$ & $15(12.3)$ & $10(8.26)$ & $5(4.13)$ & - \\
\hline & & R.S & $40(33.0)$ & $10(8.26)$ & $15(12.3)$ & $6(4.95)$ & - \\
\hline \multirow[t]{2}{*}{02} & \multirow[t]{2}{*}{ WWW } & $\mathbf{T}$ & $15(12.3)$ & $10(8.26)$ & $15(12.3)$ & $5(4.13)$ & $5(4.13)$ \\
\hline & & R.S & $10(8.26)$ & $20(16.5)$ & $25(20.6)$ & $10(8.26)$ & $5(4.13)$ \\
\hline \multirow[t]{2}{*}{03} & \multirow[t]{2}{*}{ Chatting } & $\mathbf{T}$ & $2(1.65)$ & $5(4.13)$ & $3(2.47)$ & $40(33.0)$ & - \\
\hline & & R.S & $10(8.26)$ & $5(4.13)$ & $15(12.3)$ & $41(33.8)$ & - \\
\hline \multirow[t]{2}{*}{04} & \multirow[t]{2}{*}{ Search Engines } & $\mathbf{T}$ & $12(9.91)$ & $13(10.7)$ & $10(8.26)$ & $15(12.3)$ & - \\
\hline & & R.S & $14(11.5)$ & $12(9.91)$ & $24(19.8)$ & $21(17.3)$ & - \\
\hline \multirow[t]{2}{*}{05} & \multirow[t]{2}{*}{ FTP } & $\mathbf{T}$ & $5(4.13)$ & $5(4.13)$ & $4(3.30)$ & $10(8.26)$ & $26(21.4)$ \\
\hline & & R.S & $4(3.30)$ & $6(4.95)$ & $10(8.26)$ & $20(16.5)$ & $31(25.6)$ \\
\hline \multirow[t]{2}{*}{06} & \multirow[t]{2}{*}{ Discussion Group } & $\mathbf{T}$ & $10(8.26)$ & $8(6.61)$ & $12(9.91)$ & $20(16.5)$ & - \\
\hline & & R.S & $15(12.3)$ & $5(4.13)$ & $15(12.3)$ & $36(29.7)$ & - \\
\hline \multirow{2}{*}{07} & \multirow{2}{*}{ BBS } & $\mathbf{T}$ & $4(3.30)$ & $5(4.13)$ & $6(4.95)$ & $35(28.9)$ & - \\
\hline & & R.S & $8(6.61)$ & $2(1.65)$ & $20(16.5)$ & $41(33.8)$ & - \\
\hline
\end{tabular}

Table. 9 reveal the respondents use of internet by Kurukshetra University Kurukshetra regarding various Internet services available. Most of them $90.90 \%$ of the users are always use the E-Mail service, $9.09 \%$ sometimes. More than $78.51 \%$ of the respondents are always using the WWW service, $12.39 \%$ sometimes and $8.26 \%$ never use it. Majority of them $66.94 \%$ of the respondents are sometimes used chatting service by the requirement of information need, $33.05 \%$ always. In fact $70.24 \%$ respondents are always using the search engines, $29.75 \%$ sometimes. In Life Science disciplines of K.U.K. $47.10 \%$ respondents are never used the FTP, $24.79 \%$ sometimes and also $28.09 \%$ always. Only $53.71 \%$ respondents are always using the Internet services of discussion group and $46.28 \%$ sometimes. In fact $62.80 \%$ respondents sometimes used the Bulletin Board Services and $37.19 \%$ always.

Table 10: Prefer to Read your Information

\begin{tabular}{|c|c|c|c|c|c|c|c|}
\hline Sr. No & \multicolumn{2}{|c|}{ Prefer to read your Information } & Always & Often & Usually & Sometimes & Never \\
\hline \multirow[t]{2}{*}{01} & \multirow[t]{2}{*}{ PDF } & $\mathbf{T}$ & $25(20.6)$ & $10(8.26)$ & $10(8.26)$ & $5(4.13)$ & - \\
\hline & & R.S & $20(16.5)$ & 25 (20.6) & $15(12.3)$ & $11(9.09)$ & - \\
\hline \multirow[t]{2}{*}{02} & \multirow[t]{2}{*}{ HTML } & $\mathbf{T}$ & $5(4.13)$ & $6(4.95)$ & $10(8.26)$ & $10(8.26)$ & - \\
\hline & & R.S & $10(8.26)$ & $5(4.13)$ & $5(4.13)$ & $10(8.26)$ & - \\
\hline \multirow[t]{2}{*}{03} & \multirow[t]{2}{*}{ SGML } & $\mathbf{T}$ & $2(1.65)$ & $4(3.30)$ & $6(4.95)$ & $6(4.95)$ & - \\
\hline & & R.S & $5(4.13)$ & $4(3.30)$ & $4(3.30)$ & $8(6.61)$ & - \\
\hline \multirow[t]{2}{*}{04} & \multirow[t]{2}{*}{ MS-Word } & $\mathbf{T}$ & $20(16.5)$ & $10(8.26)$ & $10(8.26)$ & $10(8.26)$ & - \\
\hline & & R.S & $15(12.3)$ & $15(12.3)$ & 25 (20.6) & $16(13.2)$ & - \\
\hline
\end{tabular}


Table 10. shows the respondents various availability use the Internet preferred to read of information by the subject of interest. PDF \& Ms-Word both are the top priority of the respondents in Kurukshetra University Kurukshetra in the disciplines of Life Science. Majority of them i.e. 86.77\% users are always using the information by PDF format, $13.22 \%$ sometimes. More than $78.51 \%$ respondents are always using the information by Ms-Word format and $21.48 \%$ sometimes. Only $33.88 \%$ users are always uses the Information by HTML format with the requirement of subject interest and $16.52 \%$ sometimes. In fact $20.66 \%$ respondents are using the SGML format and $11.57 \%$ sometimes.

Table 11: Communication Channels Used for Information-seeking

\begin{tabular}{|c|c|c|c|c|c|c|c|}
\hline Sr. No & \multicolumn{2}{|c|}{$\begin{array}{c}\text { Communication Channels Used for } \\
\text { Information Seeking }\end{array}$} & Always & Often & Usually & Sometimes & Never \\
\hline \multirow[t]{2}{*}{01} & \multirow{2}{*}{$\begin{array}{l}\text { Meeting personally / Face to face } \\
\text { discussions }\end{array}$} & $\mathbf{T}$ & $10(8.26)$ & $10(8.26)$ & $5(4.13)$ & $5(4.13)$ & - \\
\hline & & R.S & 25 (20.6) & $10(8.26)$ & $15(12.3)$ & $2(1.65)$ & - \\
\hline \multirow[t]{2}{*}{02} & \multirow[t]{2}{*}{ E-Mail } & $\mathbf{T}$ & $6(4.95)$ & $2(1.65)$ & $3(2.47)$ & - & - \\
\hline & & R.S & $2(1.65)$ & 4 (3.30) & $2(1.65)$ & - & \\
\hline \multirow[t]{2}{*}{03} & \multirow[t]{2}{*}{ Telephone } & $\mathbf{T}$ & - & - & - & - & - \\
\hline & & R.S & $2(1.65)$ & $3(2.47)$ & - & $6(4.95)$ & - \\
\hline \multirow[t]{2}{*}{04} & \multirow[t]{2}{*}{ Postal mail } & $\mathbf{T}$ & - & - & - & - & - \\
\hline & & R.S & - & - & - & - & - \\
\hline \multirow[t]{2}{*}{05} & \multirow[t]{2}{*}{ Fax } & $\mathbf{T}$ & $2(1.65)$ & $2(1.65)$ & $5(4.13)$ & - & - \\
\hline & & R.S & - & - & - & - & - \\
\hline
\end{tabular}

Table 11. shows the respondents various availability to use the communication channels for information seeking. In Life Science disciplines of $61.98 \%$ of the respondents are always using the meeting personally/face to face discussions for information seeking and $5.78 \%$ sometimes. In fact only $14.87 \%$ of the teachers \& research scholars always use the information seeking by E-Mail. Less than $4.95 \%$ sometimes respondents are uses the telephone base communication for information seeking and $4.13 \%$ always. In life science disciplines of only $7.43 \%$ of the respondents are always uses the fax for communication by the information seeking.

Table 12: Use of Search Engines by the Information Seeking

\begin{tabular}{|c|c|c|c|c|c|c|c|}
\hline Sr. No & \multicolumn{2}{|c|}{$\begin{array}{l}\text { Use of Search Engines by the } \\
\text { Information Seeking }\end{array}$} & Always & Often & Usually & Sometimes & Never \\
\hline \multirow[t]{2}{*}{01} & \multirow[t]{2}{*}{ Google.com } & $\mathbf{T}$ & $25(20.6)$ & $10(8.26)$ & $5(4.13)$ & $5(4.13)$ & - \\
\hline & & R.S & $20(16.5)$ & $10(8.26)$ & $20(16.5)$ & $10(8.26)$ & - \\
\hline \multirow[t]{2}{*}{02} & \multirow[t]{2}{*}{ Yahoo.com } & $\mathbf{T}$ & $2(1.65)$ & $2(1.65)$ & $1(0.82)$ & - & - \\
\hline & & R.S & $5(4.13)$ & $2(1.65)$ & $4(3.30)$ & - & - \\
\hline \multirow[t]{2}{*}{03} & \multirow[t]{2}{*}{ Excite.com } & $\mathbf{T}$ & - & - & - & - & - \\
\hline & & R.S & - & - & - & - & - \\
\hline \multirow[t]{2}{*}{04} & \multirow[t]{2}{*}{ Altavista.com } & $\mathbf{T}$ & - & - & - & - & - \\
\hline & & R.S & - & - & - & - & - \\
\hline
\end{tabular}

Table 12. shows that only $12.39 \%$ of the users reported that the Google.com is sometimes use while majority of respondents $74.38 \%$ that it is always use for their areas of search engines. Only $13.22 \%$ of the Life Science teachers and research scholars are always use yahoo search engine with the help of work i.e. teaching, research paper, up to date knowledge, entertainment, presentation in K.U.K.

Table 13: Information Sources that you are Need/ Access

\begin{tabular}{|c|c|c|c|c|c|c|c|}
\hline Sr. No & \multicolumn{2}{|l|}{ Information Sources } & Always & Often & Usually & Sometimes & Never \\
\hline \multirow[t]{2}{*}{01} & \multirow[t]{2}{*}{ Subject Books } & $\mathbf{T}$ & $5(4.13)$ & $10(8.26)$ & $2(1.65)$ & $30(24.7)$ & $3(2.47)$ \\
\hline & & R.S & $10(8.26)$ & $10(8.26)$ & $5(4.13)$ & $40(33.0)$ & $6(4.95)$ \\
\hline \multirow[t]{2}{*}{02} & \multirow[t]{2}{*}{ Reference Books } & $\mathbf{T}$ & $1(0.82)$ & $4(3.30)$ & $5(4.13)$ & $20(16.5)$ & $20(16.5)$ \\
\hline & & R.S & $15(12.3)$ & $1(0.82)$ & $4(3.30)$ & $30(24.7)$ & $20(16.5)$ \\
\hline \multirow[t]{2}{*}{03} & \multirow[t]{2}{*}{ Information Bulletin } & $\mathbf{T}$ & $15(12.3)$ & $10(8.26)$ & $5(4.13)$ & $20(16.5)$ & - \\
\hline & & R.S & $20(16.5)$ & $10(8.26)$ & $10(8.26)$ & $30(24.7)$ & - \\
\hline \multirow[t]{2}{*}{04} & \multirow[t]{2}{*}{ Standards } & $\mathbf{T}$ & - & - & - & $10(8.26)$ & $40(33.0)$ \\
\hline & & R.S & - & - & $2(1.65)$ & $10(8.26)$ & $59(48.7)$ \\
\hline \multirow[t]{2}{*}{05} & \multirow[t]{2}{*}{ Reprints } & $\mathbf{T}$ & $5(4.13)$ & $10(8.26)$ & $15(12.3)$ & $20(16.5)$ & - \\
\hline & & R.S & $10(8.26)$ & $15(12.3)$ & $16(13.2)$ & $30(24.7)$ & - \\
\hline \multirow[t]{2}{*}{06} & \multirow[t]{2}{*}{ Thesis/Dissertation } & $\mathbf{T}$ & - & - & - & $30(24.7)$ & $20(16.5)$ \\
\hline & & R.S & $10(8.26)$ & $5(4.13)$ & $5(4.13)$ & $41(33.8)$ & $10(8.26)$ \\
\hline \multirow[t]{2}{*}{07} & \multirow[t]{2}{*}{ Back volumes of Periodicals } & $\mathbf{T}$ & $2(1.65)$ & $4(3.30)$ & $2(1.65)$ & $22(18.1)$ & $20(16.5)$ \\
\hline & & R.S & $15(12.3)$ & $20(16.5)$ & $10(8.26)$ & $15(12.3)$ & $11(9.09)$ \\
\hline \multirow[t]{2}{*}{08} & \multirow[t]{2}{*}{ Back volumes of Newspapers } & $\mathbf{T}$ & - & - & - & $10(8.26)$ & $40(33.0)$ \\
\hline & & R.S & - & - & - & $50(41.3)$ & $21(17.3)$ \\
\hline 09 & E-Newsletters & $\mathbf{T}$ & $5(4.13)$ & $10(8.26)$ & $5(4.13)$ & $20(16.5)$ & $10(8.26)$ \\
\hline
\end{tabular}


Information Seeking Behaviour by the Research Scholars \& Faculty Members: A Survey Study .....

\begin{tabular}{|l|l|c|c|c|c|c|c|}
\hline & & R.S & $10(8.26)$ & $10(8.26)$ & $10(8.26)$ & $30(24.7)$ & $10(8.26)$ \\
\hline 10 & \multirow{2}{*}{ CD/DVD based } & T & - & $10(8.26)$ & $15(12.3)$ & $15(12.3)$ & $10(8.26)$ \\
\cline { 3 - 8 } & & R.S & $10(8.26)$ & $5(4.13)$ & $5(4.13)$ & $40(33.0)$ & $11(9.09)$ \\
\hline
\end{tabular}

In Life Science $34.71 \%$ of the respondents are always use the Subject books, $57.85 \%$ sometimes and $7.43 \%$ never use it. More than $41.32 \%$ of the users are use the reference books by sometimes in Kurukshetra University Kurukshetra, $33.05 \%$ never \& only $24.79 \%$ always use it. More than $16.52 \%$ of the users sometimes used standards, $81.81 \%$ never and $1.65 \%$ always uses it. Majority of them $41.32 \%$ respondents sometimes used the information Bulletin and $57.85 \%$ always. In Life Science $58.67 \%$ respondents are needed to reprint service always and $41.32 \%$ sometimes. More than $58.67 \%$ teachers and research scholars need to access the information by the library service most of them Thesis/Dissertation, back volumes of periodicals sometimes and $50.41 \%$ never used the back volumes of newspapers. In fact $41.32 \%$ respondents are sometimes used the E-Newspapers, also $41.32 \%$ always and $16.52 \%$ never. More than $37.19 \%$ of the users are always utilize the CD/DVD based information need to access by the K.U.K. in the disciplines of Life Science, $45.45 \%$ sometimes and $17.35 \%$ never use it.

Table 14: Methods \& Information Sources used for Current Information

\begin{tabular}{|c|c|c|c|c|c|c|c|}
\hline \multicolumn{3}{|c|}{ Methods \& Information Sources } & Always & Often & Usually & Sometimes & Never \\
\hline \multirow[t]{2}{*}{01} & \multirow[t]{2}{*}{ Consulting experts of subject field } & $\mathbf{T}$ & - & - & - & $40(33.0)$ & $10(8.26)$ \\
\hline & & R.S & $5(4.13)$ & $10(8.26)$ & $5(4.13)$ & $30(24.7)$ & $21(17.3)$ \\
\hline \multirow[t]{2}{*}{02} & \multirow[t]{2}{*}{ Reading latest books } & $\mathbf{T}$ & $2(1.65)$ & $10(8.26)$ & $8(1.65)$ & $30(24.7)$ & - \\
\hline & & R.S & $10(8.26)$ & $10(8.26)$ & $11(9.09)$ & $40(33.0)$ & - \\
\hline \multirow[t]{2}{*}{03} & \multirow[t]{2}{*}{ Reading newspapers (print and online) } & $\mathbf{T}$ & - & - & - & $10(8.26)$ & $40(33.0)$ \\
\hline & & R.S & - & - & - & $50(41.3)$ & $21(17.3)$ \\
\hline \multirow[t]{2}{*}{04} & \multirow[t]{2}{*}{ Discussions with colleagues } & $\mathbf{T}$ & $8(4.13)$ & $10(8.26)$ & $2(1.65)$ & $30(24.7)$ & - \\
\hline & & R.S & $16(8.26)$ & $10(8.26)$ & $5(4.13)$ & $40(33.0)$ & - \\
\hline \multirow[t]{2}{*}{05} & \multirow{2}{*}{$\begin{array}{l}\text { Attending Professional conferences, seminars, } \\
\& \text { workshops }\end{array}$} & $\mathbf{T}$ & $5(4.13)$ & $13(8.26)$ & $2(1.65)$ & $30(24.7)$ & - \\
\hline & & R.S & $10(8.26)$ & $16(8.26)$ & $5(4.13)$ & $40(33.0)$ & - \\
\hline \multirow[t]{2}{*}{06} & \multirow[t]{2}{*}{ Browsing shelves in bookstores } & $\mathbf{T}$ & - & - & - & $10(8.26)$ & $40(33.0)$ \\
\hline & & R.S & - & - & - & $50(41.3)$ & $21(17.3)$ \\
\hline \multirow[t]{2}{*}{07} & \multirow[t]{2}{*}{ Media: TV and Radio } & $\mathbf{T}$ & $15(12.3)$ & $10(8.26)$ & $5(4.13)$ & $20(16.5)$ & - \\
\hline & & R.S & $20(16.5)$ & $10(8.26)$ & $11(9.09)$ & $30(24.7)$ & - \\
\hline \multirow[t]{2}{*}{08} & \multirow[t]{2}{*}{ Browsing publishers' catalogues } & $\mathbf{T}$ & - & - & - & $10(8.26)$ & $40(33.0)$ \\
\hline & & R.S & - & - & - & $50(41.3)$ & $21(17.3)$ \\
\hline \multirow[t]{2}{*}{09} & \multirow{2}{*}{$\begin{array}{l}\text { Scanning current issues of print and electronic } \\
\text { journals }\end{array}$} & $\mathbf{T}$ & $5(4.13)$ & $10(8.26)$ & $15(12.3)$ & $20(16.5)$ & - \\
\hline & & R.S & $10(8.26)$ & $15(12.3)$ & $16(13.2)$ & $30(24.7)$ & - \\
\hline \multirow[t]{2}{*}{10} & \multirow[t]{2}{*}{ Reading newsletters } & $\mathbf{T}$ & $5(4.13)$ & $10(8.26)$ & $5(4.13)$ & $20(16.5)$ & $10(8.26)$ \\
\hline & & R.S & $11(9.09)$ & $10(8.26)$ & $10(8.26)$ & $30(24.7)$ & $10(8.26)$ \\
\hline \multirow[t]{2}{*}{11} & \multirow{2}{*}{$\begin{array}{l}\text { Through current awareness services of libraries } \\
\text { like CAS,SDI \& Content Page }\end{array}$} & $\mathbf{T}$ & $15(12.3)$ & $10(8.26)$ & $5(4.13)$ & $20(16.5)$ & - \\
\hline & & R.S & $20(16.5)$ & $10(8.26)$ & $11(9.09)$ & $30(24.7)$ & - \\
\hline \multirow[t]{2}{*}{12} & \multirow{2}{*}{$\begin{array}{l}\text { Scanning recent issues of abstracting and } \\
\text { Indexing tools }\end{array}$} & $\mathbf{T}$ & $10(8.26)$ & $5(4.13)$ & $15(12.3)$ & $20(16.5)$ & - \\
\hline & & R.S & $10(8.26)$ & $15(12.3)$ & $16(13.2)$ & $30(24.7)$ & - \\
\hline \multirow[t]{2}{*}{13} & \multirow[t]{2}{*}{ Through email alerts (Listserv) } & $\mathbf{T}$ & - & $10(8.26)$ & $15(12.3)$ & $15(12.3)$ & $10(8.26)$ \\
\hline & & R.S & $10(8.26)$ & $5(4.13)$ & $5(4.13)$ & $40(33.0)$ & $11(9.09)$ \\
\hline
\end{tabular}

Table 14. shows that only $25.61 \%$ of the users reported that the consulting experts of subject field are never use while only $57.85 \%$ of the users that it is sometimes use for their methods \& information sources, $16.52 \%$ always use it. More than $42.14 \%$ of the Life science respondents used the information sources such as discussions with colleagues, reading latest books, attending professional conferences/seminars/workshops are always use it and $57.85 \%$ sometimes. Both of them $49.85 \%$ sometimes respondents are access the information by reading the newspapers and browsing publishers catalogues and 50.41\% never use it. 58.67\% teachers and research scholars stated that the access of information sources i.e. TV, Radio, scanning current issues of print and electronic journals, CAS, SDI, Content page and also abstracting/indexing tools are always used in Kurukshetra University Kurukshetra and $41.32 \%$ sometimes. Reading newsletters are always useful to access the information i.e. $42.14 \%$ of the users, $41.32 \%$ sometimes and also $16.52 \%$ never use it. In fact $37.19 \%$ of the users stated that the email alerts services are always useful about the access of information, $45.45 \%$ sometimes \& also $17.35 \%$ never.

Table 15: Problems Faced by Users in Information-Seeking

\begin{tabular}{|c|c|c|c|c|c|c|c|}
\hline S. $\mathbf{N}$ & Problems Faced by Users & & $\begin{array}{l}\text { Strongly } \\
\text { Agree }\end{array}$ & Agree & $\begin{array}{l}\text { Not } \\
\text { Sure }\end{array}$ & Disagree & $\begin{array}{l}\text { Strongly } \\
\text { Disagree }\end{array}$ \\
\hline \multirow[t]{2}{*}{01} & \multirow[t]{2}{*}{ Required material is not available } & $\mathbf{T}$ & - & $10(8.26)$ & $10(8.26)$ & $30(24.7)$ & - \\
\hline & & R.S & - & $30(24.7)$ & $10(8.26)$ & 31 (25.6) & - \\
\hline \multirow[t]{2}{*}{02} & \multirow{2}{*}{$\begin{array}{l}\text { Information is scattered in too many } \\
\text { sources }\end{array}$} & $\mathbf{T}$ & $10(8.26)$ & $10(8.26)$ & $30(24.7)$ & - & - \\
\hline & & R.S & $20(16.5)$ & $20(16.5)$ & 31 (25.6) & - & - \\
\hline \multirow[t]{2}{*}{03} & \multirow[t]{2}{*}{ Information sources are very expensive } & $\mathbf{T}$ & - & $20(16.5)$ & $30(24.7)$ & - & - \\
\hline & & R.S & - & $30(24.7)$ & $41(33.8)$ & - & - \\
\hline
\end{tabular}


Information Seeking Behaviour by the Research Scholars \& Faculty Members: A Survey Study .....

\begin{tabular}{|c|c|c|c|c|c|c|c|}
\hline \multirow[t]{2}{*}{04} & \multirow{2}{*}{ Information sources are located far away } & $\mathbf{T}$ & - & - & - & - & - \\
\hline & & R.S & - & - & - & - & - \\
\hline \multirow[t]{2}{*}{05} & \multirow[t]{2}{*}{ Latest information sources are not available } & $\mathbf{T}$ & - & - & $40(33.0)$ & $10(8.26)$ & - \\
\hline & & R.S & $41(33.8)$ & - & $20(16.5)$ & $10(8.26)$ & - \\
\hline \multirow[t]{2}{*}{06} & \multirow{2}{*}{$\begin{array}{l}\text { Information explosion or too much } \\
\text { information }\end{array}$} & $\mathbf{T}$ & - & - & - & - & - \\
\hline & & R.S & - & - & - & - & - \\
\hline \multirow[t]{2}{*}{07} & \multirow[t]{2}{*}{ Lack of time for searching } & $\mathbf{T}$ & $40(33.0)$ & - & $10(8.26)$ & - & - \\
\hline & & R.S & $51(42.1)$ & - & $20(16.5)$ & - & - \\
\hline \multirow[t]{2}{*}{08} & \multirow{2}{*}{$\begin{array}{l}\text { Non availability of E-Resource (E-journals \& } \\
\text { databases) }\end{array}$} & $\mathbf{T}$ & - & - & - & $20(16.5)$ & $30(24.7)$ \\
\hline & & R.S & - & - & - & $30(24.7)$ & $41(33.8)$ \\
\hline \multirow[t]{2}{*}{09} & \multirow[t]{2}{*}{ Too many classes or administrative work } & $\mathbf{T}$ & $20(16.5)$ & $10(8.26)$ & $20(16.5)$ & - & - \\
\hline & & R.S & $05(4.13)$ & $05(4.13)$ & $61(50.4)$ & - & - \\
\hline \multirow[t]{2}{*}{10} & \multirow{2}{*}{$\begin{array}{l}\text { Lack of training in electronic resources/ } \\
\text { products }\end{array}$} & $\mathbf{T}$ & $30(24.7)$ & $10(8.26)$ & $10(8.26)$ & - & - \\
\hline & & R.S & $40(33.0)$ & $20(16.5)$ & $11(9.09)$ & - & - \\
\hline \multirow[t]{2}{*}{11} & \multirow[t]{2}{*}{ Language } & $\mathbf{T}$ & - & - & $20(16.5)$ & - & $30(24.7)$ \\
\hline & & R.S & - & - & $40(33.0)$ & - & $31(25.6)$ \\
\hline
\end{tabular}

Table 15. indicates that $33.05 \%$ of the users are agree by required material are not available in the library, $16.52 \%$ not sure and $50.41 \%$ disagree. $24.79 \%$ of the Life Science teachers \& research scholars are strongly agree reported the inability of the information are scattered in too many sources available in library, $24.79 \%$ agree and $50.41 \%$ Not sure with the statement. Most of the $41.32 \%$ respondents are strongly agreed get the information sources are very expensive and $58.67 \%$ not sure in the field of subject. In fact $33.88 \%$ respondents are strongly agreed get the latest information sources are not available in Kurukshetra University Kurukshetra in the disciplines of Life Science, $49.58 \%$ not sure and $16.52 \%$ disagree with the statement. More than $75.20 \%$ users are strongly agreed with the statement lack of time for searching and $24.79 \%$ not sure. In Life Science disciplines of $41.32 \%$ teachers and research scholars are disagree with the statement non availability of EResource (E-Journals \& Database) in Kurukshetra University Kurukshetra and 58.67\% strongly disagreed. Only $20.66 \%$ users are strongly agreed too many classes or administrative work, $12.39 \%$ agreed and $66.94 \%$ not sure with the statement. Majority of them $57.85 \%$ teachers \& research scholars are strongly agree reported the lack of training in electronic resources/products available in Kurukshetra University Kurukshetra, 24.79\% agree and $17.35 \%$ not sure with the statement. $49.58 \%$ users are not sure with the statement of problem with language and $50.41 \%$ strongly disagree in the subject of field.

\section{Finding Of The Survey}

* Information Seeking of Kurukshetra University Kurukshetra in the disciplines of Life Science users used more by females i.e. $52.89 \%$ than male users.

* K.U.K in the disciplines of Life Science users access the information i.e. 58.67\% research scholar, professors $8.26 \%$ than the junior faculty members.

* $28.92 \%$ respondents were always using the Information need to access by the library daily and same $28.92 \%$ sometimes.

* K.U.K in the disciplines of Life Science $22.31 \%$ users used the information to access weekly, and $16.52 \%$ twice in a week.

* In Life Science $95.04 \%$ users were always use/access the Information for research works and $4.13 \%$ sometimes, and education purpose were the second purpose for which users always access the Information i.e. $90.90 \%$ and $9.09 \%$ sometimes.

* Entertainment were the third purpose for using the library i.e. $53.71 \%$ users always \& $45.45 \%$ sometimes. Update knowledge were the forth purpose for which users always access the information i.e. $49.58 \%$, in fact $33.05 \%$ sometimes and $16.52 \%$ never.

* Only $43.80 \%$ respondents were always access the information by the writing \& presenting paper, $34.71 \%$ sometimes \& $16.52 \%$ never.

* In Life Science disciplines of $41.32 \%$ users were access and utilize the information by teaching purpose of KUK \& $12.39 \%$ sometimes.

* $16.52 \%$ users were always carrying out the administrative work of KUK, $33.05 \%$ sometimes and $8.26 \%$ never with the statement.

* $32.23 \%$ respondents were always using the Information by departmental library and $5.78 \%$ sometimes. In fact KUK in the disciplines of Life Science i.e. $20.66 \%$ users were always uses the information by home, $5.78 \%$ sometimes with the requirement of information needs.

* Only $9.91 \%$ teachers and research scholars were use the information by office and $9.09 \%$ central library of Kurukshetra.

* Life Science teachers and research scholars were spend more times in the library. 32.23\% respondents were 1 to 2 hours always time spending on library by the requirement of information needs. 
* In fact $42.97 \%$ of the users spend less than 30 Minutes to 1 hour, $16.52 \%$ sometimes. Only $7.43 \%$ Teachers \& Research scholars were spent their 2 to 3 hours and very less than $0.82 \%$ users were always use/access the information on library by 3 to 4 hours in the discipline of life Science from KUK.

* $53.71 \%$ of the respondents were always using the Internet services 2 to 3 times in a week from K.U.K. In fact only $23.14 \%$ of the users were daily use the Internet services, $19 \%$ sometimes. In Life Science disciplines of $4.13 \%$ respondents were always using the Internet services 3 to 5 times in a month.

* E-Journals \& E-Books both were the top priority of the respondents in K.U.K in the disciplines of Life Science. More than $61.98 \%$ respondents were always using the E-books under the Internet resources, $24.79 \%$ sometimes and $13.22 \%$ never use it. In fact $82.64 \%$ users were always using the EJournals and $16.52 \%$ sometimes with the statement.

* Only $47.10 \%$ respondents were always using the E-database, $28.92 \%$ sometimes and $13.22 \%$ never use it with the requirement of Information need. In fact $47.10 \%$ teachers \& research scholars were always using the E-thesis/Dissertation and $28.92 \%$ sometimes by the subject of field.

* The respondents were use of internet by K.U.K regarding the various Internet services. Most of them $90.90 \%$ of the users always use the E-Mail service, $9.09 \%$ sometimes. More than $78.51 \%$ of the respondents were always using the WWW service, $12.39 \%$ sometimes and $8.26 \%$ never use it.

* Majority of them $66.94 \%$ users were sometimes used chatting service by the purpose of information need, $33.05 \%$ always. Again $70.24 \%$ respondents were always using the search engines service, $29.75 \%$ sometimes.

* In Life Science disciplines of K.U.K 47.10\% respondents were never used the FTP, 24.79\% sometimes and $28.09 \%$ always. Only $53.71 \%$ respondents were always using the Internet services with discussion group and $46.28 \%$ sometimes. In fact $62.80 \%$ respondents were sometimes used the Bulletin Board Services, $37.19 \%$ always.

* The respondents were various availability uses the Internet preferred to read information by the subject of interest. PDF \& Ms-Word both were the top priority of the respondents in K.U.K in the disciplines of Life Science. Majority of them i.e. $86.77 \%$ users were always using the information by PDF format and $13.22 \%$ sometimes.

* Majority of them $78.51 \%$ respondents were always using the information by Ms-Word format, $21.48 \%$ sometimes. Only $33.88 \%$ users use the HTML format and $16.52 \%$ sometimes.

* In fact $20.66 \%$ respondents were using the information by SGML format and $11.57 \%$ sometimes.

* In Life Science disciplines of $61.98 \%$ respondents were always using the meeting personally/face to face discussions for information seeking and $5.78 \%$ sometimes.

* In fact only $14.87 \%$ of the teachers \& research scholars always use the information seeking by E-Mail. Less than $4.95 \%$ sometimes respondents were uses the telephone base communication for information seeking and $4.13 \%$ always. Only $7.43 \%$ of the respondents were always uses the fax for communication by the information seeking.

* Only $12.39 \%$ of the users reported that the Google.com were sometimes use while majority of $74.38 \%$ of the respondents that it is always use for their areas of search engines. Only $13.22 \%$ of the Life Science teachers and research scholars were always use yahoo search engine with the help of work i.e. teaching, research paper, up to date knowledge, entertainment, presentation in Kurukshetra University Kurukshetra.

- $34.71 \%$ of the respondents were always using the Subject books, $57.85 \%$ sometimes and $7.43 \%$ never use it.

* More than $41.32 \%$ of the users were use the reference books by sometimes in K.U.K, $33.05 \%$ never \& only $24.79 \%$ always use it. More than $16.52 \%$ of the users sometimes used standards, $81.81 \%$ never and $1.65 \%$ always uses it.

* $41.32 \%$ respondents were sometimes used the information Bulletin and $57.85 \%$ always. In Life Science $58.67 \%$ respondents need to reprint services always and $41.32 \%$ sometimes. More than $58.67 \%$ teachers and research scholars need to access the information by the library service most of them Thesis/Dissertation, back volumes of periodicals sometimes and $50.41 \%$ never used the back volumes of newspapers.

* In fact $41.32 \%$ respondents were sometimes used the E-Newspapers, also $41.32 \%$ always and $16.52 \%$ never. More than $37.19 \%$ of the users were always utilize the CD/DVD based information need to access by the K.U.K in the disciplines of Life Science, $45.45 \%$ sometimes and $17.35 \%$ never use it.

* Only $25.61 \%$ of the users reported that the consulting experts of subject field is never use while only $57.85 \%$ of the users that it is sometimes use for their methods \& information sources, $16.52 \%$ always use it.

* More than $42.14 \%$ of the Life science respondents used those information sources such as discussions with colleagues, reading latest books, attending professional conferences/seminars/workshops are always use it and $57.85 \%$ sometimes. 
* Both of them $49.85 \%$ sometimes respondents were access the information with reading the newspapers and browsing publishers catalogues and $50.41 \%$ never use it.

* $58.67 \%$ teachers and research scholars stated that the access of information sources i.e. TV, Radio, scanning current issues of print and electronic journals, CAS, SDI, Content page and also abstracting/indexing tools were always used in K.U.K and $41.32 \%$ sometimes.

* Reading newsletters were always useful to access the information i.e. $42.14 \%$ of the respondents, $41.32 \%$ sometimes and also $16.52 \%$ never use it.

* In fact $37.19 \%$ of the users stated that the email alerts services were always useful about the access of information, $45.45 \%$ sometimes \& also $17.35 \%$ never.

* Majority of them $33.05 \%$ of the users were agreeing by required material were not available in the library, $16.52 \%$ not sure and $50.41 \%$ disagree. $24.79 \%$ of the Life Science teachers \& research scholars were strongly agree reported the inability of the information were scattered in too many sources available in library, $24.79 \%$ agree and $50.41 \%$ Not sure with the statement.

* Most of the $41.32 \%$ respondents were strongly agreed get the information sources were very expensive and $58.67 \%$ not sure in the field of subject. In fact $33.88 \%$ respondents were strongly agreed get the latest information sources were not available in K.U.K in the disciplines of Life Science, $49.58 \%$ not sure and $16.52 \%$ disagree with the statement.

* More than $75.20 \%$ users were strongly agreed with the statement lack of time for searching and $24.79 \%$ not sure. In Life Science disciplines of $41.32 \%$ teachers and research scholars were disagree with the statement non availability of E-Resource (E-Journals \& Database) in K.U.K and 58.67\% strongly disagreed.

* Only $20.66 \%$ users were strongly agreed too many classes or administrative work, $12.39 \%$ agreed and $66.94 \%$ not sure with the statement.

* Majority of them $57.85 \%$ teachers \& research scholars were strongly agree reported the lack of training in electronic resources/products available in K.U.K, $24.79 \%$ agree and $17.35 \%$ not sure with the statement.

* In fact $49.58 \%$ users were not sure with the statement of problem with language and $50.41 \%$ strongly disagree in the subject of field.

Based on the findings, the following Suggestions are put forward to improve the Information Seeking Behaviour in Kurukshetra University Library.

* The speed of Internet should be increased so that the respondents can speedily access the information and utilize the information by the important work i.e. research work, education work, writing paper/presenting paper, administrative work, entertainment and also their download relevant materials.

* Library should organize training programme for the information professionals so that they can know about different search interface, latest changes of the journals site and develop sophisticated searching and retrieval skills or techniques.

* The library should provide sufficient number of computer with internet access.

* Availability of network on Saturdays evening hours and holidays was very poor. It should be improved.

* The library must take steps to improve the use of internet \& E-Journals, organize training programmes in using internet \& other E-resources, E-Journals etc. \& measures to improve the journal usage should also be taken up.

* The library needs to aware the students about E-Journals \& E-Resources available in INFLIBNET.

\section{Acknowledgements}

First and foremost, I would like to thank the almighty God (Jesus Christ) the most beneficent and merciful, who blessed me for completing this work. It is not possible to record in words the inspirational guidance of my father Sh. Som Nath kapoor, Mother Shanti devi \& also Brother Dr. Ajay Kapoor. I am also thanks to my sister Anju Dhingra and Tarun Dhingra the inspirational \& motivational guidance.

\section{References}

[1]. Asemi. Information searching habits of Internet users: A case study on the Medical Sciences University of lsfahan: lran.2005 [cited 30 April 2014] Available http://'www.webology.ir/2005/v2nl./al0.html.

[2]. G. T. Shakeel and P. Vinayagamoorthy. Information Seeking Behaviour of business school students: A special study of universities and colleges located in Academic City, Dubai: UAE. International Journal of Library and Information Science 5(11), 2013, 447-456

[3]. Dervin and M. Milan. Information needs and uses in: Annual Review of Information Science and Technology. Knowledge Industry Publication: New York, 1986, 3-33.

[4]. C.S. Turnor. Organizing Information principles \& practice. Clive Bingley: London, 1998, 217-255.

[5]. B. Ramesh. Information Seeking Behavior of Faculty Members of ICFAI Business School: Hyderabad. International Journal of Information Dissemination \& Technology, 2012 1(4) [cited 26 April 2014] Available http://.ijidt.com/index.php/ijidt/article/view/69

[6]. George et al. Scholars use of information: Graduate students Information Seeking Behavior. Information Research 11(4), $2006,2-6$.

[7]. J. Krikelas. Information Seeking Behavior: A pattern and concept. Library Quarterly: Drexel 19(2), 1983, 5-20. 
[8]. J. K. Bhatia and P.V. Rao. Information seeking behavior of students in digital environment: A case study. $8^{\text {th }}$ International conference on Caliber, 2011, Goa University: Goa. [cited 30 April 2014] Available http://ir.inflibnet.ac.in/dxml/bitstrem/handle/1637/45.pdf.

[9]. J. Heinstrom. Fast surfing broad scanning and deep diving: The influence of personality and study approach on student's Information Seeking Behaviour. Journal of Documentation 61(2), 2005, 228- 247.

[10]. J. Purnima and D.Vikas. A study of college faculties in Manipur. ILA Bulletin 41(2), 2005, 156-19.

[11]. J. Roberts. Senior student nurses Information Seeking skills: A comparative study 24(3), 2004, 211 - 218

[12]. K. Rupp-Serrano and S. Robbins. Information Seeking Habits of Education Faculty. College \& research libraries 74(2), 2013,2131 142.

[13]. Liao et al. Information Seeking Behavior of international graduate student's vs Ameican graduate students: A user study at Virginia tech 2005. College \& Research Libraries 68(1), 2007, 5-25.

[14]. Majeed et al. Information needs and information seeking behavior of Agricultural scientists in Malaysia. Library \& Information Science Research 22(2), 2000, 145-163.

[15]. M. M. Raja. Information Seeking Behavior of researchers in central drug research institute (CDRI). Library Philosophy and Practice: Lucknow, 2010. [cited 30 April 2014] Available http://faqs.org/paridicals/201006/2095013421.html

[16]. M. Natarajan. Exploring the E-Resources for Educational Use. NISCAIR 1(4), 2012, 193-96.

[17]. N. J. Belkin. Information concept for Information Science. Journal of Documentation 34 (1), 1978, 55-58

[18]. Nicholas et al. Searching intention \& Information outcome: A case study of digital health information: Libri 51(3), 2001, 157-166.

[19]. Parveen Kumar. Information Seeking Behaviour of Faculty Members at BPS Mahila Vishwavidyalaya, Khanpur Kalan. A Journal of Library and Information Science 7(1), 2013, 1-4

[20]. P. Prekop. A qualitative study of collaborative Information Seeking. Journal of Documentation 58(5), 2002, 533-547.

[21]. P. Wang. Information behaviors of academic researchers in the internet era: An interdisciplinary \& cross-cultural study, 2006 [cited 30 April 2014] Available http://dlist.sir.arizona.edu/ 1664/01/eRA PeilingWang.pdf.

[22]. P. Wasserman. Information transfer in science \& technology: An overview. Asian Libraries 1(2), 1991, 27-38.

[23]. Qureshi et al. Information needs \& Information Seeking Behavior of students in Universities of Pakistan. Journal of Applied Sciences Research 4(1), 2008, 40-47.

[24]. R. S. Taylor. Information use environment. In: Brenda Derwin and Melvin J. Voist (eds). Progress in communication science: Norwood, 1991.

[25]. S. A. Khan and F. Shafique. Information needs \& Information seeking behavior: A survey of college facility at Bahawalpur. Library Philosophy and Practice, 2011 [cited 30 April 2014] Available http://digitalcommons.edu/cgi/view.content/cgi?article 1502.

[26]. S. E. Wiberlay and W. G. Jones. Patterns of Information Seeking in the humanities. College \& research libraries 19(1), 1989, 17-26.

[27]. S. Hiller. How different are they: A comparison by academic area of library use, priorities, and Information needs at University of Washington. Science and Technology Librarianship, 2002 [cited 26 April 2014] Available http://www.istl.org/02-winter/'artic.

[28]. S. Kim and H. Choi. Still hungry for information: Information Seeking Behavior of senior citizens in South Korea. Conference proceedings on Seoul National University, 2014, 889-894.

[29]. Tenopir et al. Electronic Journals and changes in scholarly article seeking and reading patterns. ASLIB Proceedings: New Information Perspectives 61(1), 2009, 5-32.

\section{About Author}

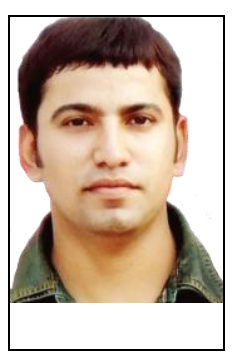

Anil kapoor is presently Librarian (H.O.D in Library) in the Swift group of Colleges Rajpura, Patiala. He holds a Ph.D (Pursuing) in Library \& Information science from Kurukshetra University Kurukshetra. He published than 4 research paper in National \& International professional journals.

E-Mail: anilkapoorkapoor@rediffmail.com,

E-Mail: dranilkapoor83@ gmail.com

Appendix - 1

Questionnaire for Users

Personal information (Please $(\checkmark)$ Mark in the appropriate boxes)

Name:

Department:

Sex:Female/Male

Status: (tick one): Professor/Reader/Lecturer/Research scholar

\section{Information Seeking Behaviour}

* Do you visit the Library?

\begin{tabular}{|c|l|l|l|l|l|l|}
\hline \multicolumn{2}{|c|}{ Visit the Library } & Always & Often & Usually & Sometimes & Never \\
\hline 1. & Daily & & & & & \\
\hline 2. & Weekly & & & & & \\
\hline 3. & Thrice in a week & & & & & \\
\hline 4. & Occasionally & & & & & \\
\hline
\end{tabular}

* What is the purpose/need of Information Seeking? (You may $\checkmark$ more than one option ) 
Information Seeking Behaviour by the Research Scholars \& Faculty Members: A Survey Study .....

\begin{tabular}{|c|l|l|l|l|l|l|}
\hline \multicolumn{2}{|c|}{ Purpose of Information Seeking } & Always & Often & Usually & Sometimes & Never \\
\hline 1. & Teaching & & & & & \\
\hline 2. & Research Work & & & & & \\
\hline 3. & Education & & & & & \\
\hline 4. & writing paper \& presenting paper & & & & & \\
\hline 5. & updating knowledge & & & & & \\
\hline 6. & Entertainment & & & & & \\
\hline 7. & Carry out administrative work & & & & & \\
\hline
\end{tabular}

* Where do you use/prefer to use Information?

\begin{tabular}{|c|l|c|c|c|c|c|}
\hline \multicolumn{2}{|c|}{ Prefer to use Information } & Always & Often & Usually & Sometimes & Never \\
\hline 1. & Home & & & & \\
\hline 2. & Departmental Library & & & & \\
\hline 3. & Office & & & & \\
\hline 4. & Central Library of the University & & & & \\
\hline
\end{tabular}

* Average time spent in the library on the visit of Information need?

\begin{tabular}{|c|l|c|c|c|c|c|}
\hline \multicolumn{2}{|c|}{ Time Spent in the library } & Always & Often & Usually & Sometimes & Never \\
\hline 1. & Less than 30Minutes to 1 hour & & & & \\
\hline 2. & 1 to 2 hours & & & & \\
\hline 3. & 2 to 3 hours & & & & \\
\hline 4. & 3 to 4 hours & & & & \\
\hline 5. & More the 4 hours & & & & \\
\hline
\end{tabular}

* Do you Use Internet Resources? Yes/No

If, yes which of the following resources you regularly use

\begin{tabular}{|c|l|l|l|l|l|l|}
\hline \multicolumn{2}{|c|}{ Use Internet resources } & Always & Often & Usually & Sometimes & Never \\
\hline 1. & E-Books & & & & & \\
\hline 2. & E-Journals & & & & & \\
\hline 3. & E-database & & & & & \\
\hline 4. & E-Thesis/Dissertation & & & & & \\
\hline
\end{tabular}

* Internet based Information Services? (You may $\checkmark$ more than one option )

\begin{tabular}{|c|l|c|c|c|c|c|}
\hline \multicolumn{2}{|c|}{ Internet Services } & Always & Often & Usually & Sometimes & Never \\
\hline 1. & E-mail & & & & & \\
\hline 2. & WWW & & & & & \\
\hline 3. & Chatting & & & & & \\
\hline 4. & Remote login (Telnet) & & & & & \\
\hline 5. & FTP & & & & & \\
\hline 6. & Discussion Group & & & & & \\
\hline 7. & BBS & & & & & \\
\hline
\end{tabular}

* In what format would you prefer to Read your Information?

Format to read your Information

\begin{tabular}{|c|l|l|l|l|l|l|}
\hline \multicolumn{2}{|c|}{ Format to read your Information } & Always & Often & Usually & Sometimes & Never \\
\hline 1. & PDF & & & & \\
\hline 2. & HTML & & & & \\
\hline 3. & SGML & & & & \\
\hline 4. & Ms Word & & & & \\
\hline
\end{tabular}

* Communication Channels Used for Information-seeking

\begin{tabular}{|c|l|l|l|l|c|c|}
\hline \multicolumn{2}{|c|}{ Communication Channels } & Always & Often & Usually & Sometimes & Never \\
\hline 1. & $\begin{array}{l}\text { Meeting personally / Face to face } \\
\text { discussions }\end{array}$ & & & & \\
\hline 2. & E-Mail & & & & & \\
\hline 3. & Telephone & & & & & \\
\hline 4. & Postal mail & & & & & \\
\hline 5. & fax & & & & \\
\hline
\end{tabular}

* Please tick ( $\square$ ) the Information Sources that you are need/access to find? (You may $\checkmark$ more than one option ) Information Sources Always

Often

Usually

Sometimes

Never 
Information Seeking Behaviour by the Research Scholars \& Faculty Members: A Survey Study .....

\begin{tabular}{|l|l|l|l|l|l|}
\hline 1. & Subject Books & & & & \\
\hline 2. & Reference Books & & & & \\
\hline 3. & Information Bulletin & & & & \\
\hline 4. & Standards & & & & \\
\hline 5. & Reprints & & & & \\
\hline 6. & Thesis/Dissertation & & & & \\
\hline 7. & Back volumes of Periodicals & & & & \\
\hline 8. & Back volumes of Newspapers & & & & \\
\hline 9. & E-Journals & & & & \\
\hline 10. & E-Books & & & & \\
\hline 11 & E-Newsletters & & & & \\
\hline 12. & CD/DVD based & & & \\
\hline
\end{tabular}

* Methods and Sources Used for Current Awareness (You may $\checkmark$ more than one option )

\begin{tabular}{|c|c|c|c|c|c|c|}
\hline \multicolumn{2}{|r|}{ Sources to used for Current Awareness } & Always & Often & Usually & Some & Never \\
\hline 1. & Consulting experts in subject field & & & & & \\
\hline 2. & Reading latest books & & & & & \\
\hline 3. & Reading newspapers (print and online) & & & & & \\
\hline 4. & Discussions with colleagues & & & & & \\
\hline 5. & Attending professional conferences, seminars, and workshops & & & & & \\
\hline 6. & Browsing shelves in bookstores & & & & & \\
\hline 7. & Browsing publishers' catalogues & & & & & \\
\hline 8. & Media: TV and radio & & & & & \\
\hline 9. & Scanning current issues of print and electronic journals & & & & & \\
\hline 10. & Reading newsletters & & & & & \\
\hline 11. & Through current awareness services of libraries like CAS, SDI \& Content Page Service & & & & & \\
\hline 12. & Scanning recent issues of abstracting and indexing tools & & & & & \\
\hline 13 & Through email alerts (Listserv) & & & & & \\
\hline
\end{tabular}

* Problems Faced by Respondents to Information-Seeking? (You may $\checkmark$ more than one option )

\begin{tabular}{|c|c|c|c|c|c|c|}
\hline \multicolumn{2}{|r|}{ Problems faced by users to Information Seeking } & \multirow{2}{*}{$\begin{array}{c}\text { Strongly } \\
\text { Agree }\end{array}$} & \multirow[t]{2}{*}{ Agree } & \multirow{2}{*}{$\begin{array}{l}\text { Not } \\
\text { Sure }\end{array}$} & \multirow[t]{2}{*}{ Disagree } & \multirow{2}{*}{$\begin{array}{l}\text { Strongly } \\
\text { Disagree } \\
\end{array}$} \\
\hline 1. & Required material is not available & & & & & \\
\hline 2. & Information is scattered in too many sources & & & & & \\
\hline 3. & Information sources are very expensive & & & & & \\
\hline 4. & Information sources are located far away & & & & & \\
\hline 5. & Latest information sources are not available & & & & & \\
\hline 6. & Information explosion or too much information & & & & & \\
\hline 7. & Lack of time for searching & & & & & \\
\hline 8. & Non availability of electronic resource (e-journals \& databases) & & & & & \\
\hline 9. & Too many classes or administrative work & & & & & \\
\hline 10. & Lack of training in electronic resources/products & & & & & \\
\hline 11. & Language & & & & & \\
\hline
\end{tabular}

\section{Any other suggestion to improve the Information seeking behavior in K.U.K}

\section{Signature}

\section{Thanks for your cooperation}

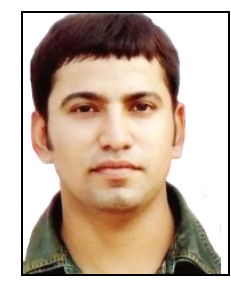

E-Mail: anilkapoorkapoor@ rediffmail.com,

E-Mail: dranilkapoor83@gmail.com 